\title{
ANDRZEJ NUSANTARA WAWRZYNIAK AND HIS INDONESIAN COLLECTION AT THE ASIA AND PACIFIC MUSEUM IN WARSAW ${ }^{1}$
}

Collecting Asian art - or non-European art in general - was never a major focus of Polish museums. Polish museology emerged under conditions of the $19^{\text {th }}$-century partition of the country, which, in these circumstances, not only could not expand as a colonial power, but also was itself in the position of being subordinated or 'colonised'. Then, the focus of collections - both public and many private ones - was mostly on the preservation and promotion of national heritage, as was also the case for other nations deprived of political autonomy during that period. ${ }^{2}$ Historical and very important collections originating from Turkey and other Islamic countries were interpreted and admired mostly as documents of national history and pride of past victories. Numerous objects of Chinese and Japanese export art functioned indeed as elements of interior decoration. However, although the theoretical reflection on non-European art traditions appeared early enough in Poland - in the writings of Stanislaw Kostka Potocki (1755-1821) ${ }^{3}$, himself a collector - it was not followed by systematic or large-scale collecting in this area. A splendid and extremely important $19^{\text {th }}$-century collection is that of Feliks 'Manggha' Jasieński (1861-1929), which focused on purely aesthetic aspects of Japanese art, as seen by the Western-European Japonism of the period; significantly, Jasieński never visited Japan himself. ${ }^{4}$

The short period of regained independence (1918-39) did not bring important changes in this regard, despite Poland's unfulfilled colonial ambitions.

Nevertheless, some private and public collections were expanding. Unfortunately, a major part of these early resources fell victim to World War II.

After the war, when Poland became a part of the Soviet political bloc, the contacts with Soviet-influenced or allied non-European countries became an important aspect in Polish foreign affairs. Though strictly official and relatively limited, they were a source of knowledge about countries and cultures almost entirely unknown before. Besides China and India, Vietnam, North Korea, Mongolia and other countries were also officially promoted and presented as political and economic partners and declared friends, although the 'exotic' aspects of their cultures were also strongly emphasised as being attractive and appealing to the audience. Though limited in numbers, the Polish travellers included journalists, artists, ${ }^{5}$ specialists sent as experts to these countries, and, of course, ethnologists, Oriental-studies scholars and other academic researchers.

It was in such an environment that Andrzej Wawrzyniak, founder of the Asia and Pacific Museum (APM) in Warsaw, began his career as a collector. Born in 1931, he became a sailor and in 1950 first reached Asia as a young officer in the Polish merchant marine. In the 1950s he changed his profession and starting working in foreign affairs. One of his first posts was Vietnam $_{0}$ where $9: 26 \mathrm{AM}$ he was a member of the International Commission for the Supervision and access 
Control in Vietnam (1956-60); this was also the beginning of his fascination with Asian art and culture.

Probably the most important period of his life began when he started working in Jakarta, first as the cultural attache of the Polish embassy (1961-65) and later as the deputy head of the mission and chargé d'affaires in the years 1967-71. Avidly interested in the culture of the country he soon started calling his second motherland, ${ }^{6}$ over a ten-year period he amassed more than 4000 Indonesian objects, a unique collection of this kind in Poland.

After finishing his mission in Indonesia, and unable to manage a collection of this scale as a private owner while still active in the diplomatic service, Wawrzyniak decided to donate it to the Polish state if a new, independent museum would be founded for the occasion. Consequently, Nusantara Archipelago Museum was founded in Warsaw in 1973 and renamed the Asia and Pacific Museum in 1976. Andrzej Wawrzyniak was appointed director for life of the institute, which was created thanks to his generosity; he still fills this post today.

At that time, Indonesian collections in Polish ethnological museums were rare and rather marginal. The most interesting ones were the remains of collections gathered by Marian Raciborski and Michal Siedlecki, Polish botanists working in the early $20^{\text {th }}$ century in the Dutch Indies, and preserved in the Ethnographic Museum. Unfortunately, they were devastated during World War II. Because of this, Wawrzyniak's collection was appreciated as having a unique value.

\section{The beginning and the collection}

How was it created? As many collections, this one was also born of fascination and very personal experiences. Andrzej Wawrzyniak first became interested in side arms - a gentleman's hobby which quickly became a true passion. Keris with magical stories accompanying them strongly influenced the collector's imagination. Recalling those years, he recounts meeting a dukun somewhere on the roadside near Semarang, who was selling rings with magical stones. The shaman used a keris to choose a suitable ring for his customer and while bargaining for it, Andrzej Wawrzyniak caught sight of a piece of rusty, dirty iron among the rings and stones. When asked, the dukun said that this was an object of great power, but he finally agreed to sell it. After meticulous cleaning and consultation at the Museum Nasional in Jakarta, the object turned out to be a Majapahit type of early keris, with the blade and hilt forged from a single piece of iron (fig. 1). ${ }^{7}$

Over 10 years Andrzej Wawrzyniak gathered around 450 weapons, making the collection one of the most important of its kind outside Indonesia. Kerises dominate, representing different local types from Java (Yogyakarta, Solo, Cirebon) and other islands (Madura, Bali, Sumatra, Sulawesi). Wawrzyniak shared to some degree his friends' approach to the precious keris, inviting the empu specialists during his stay in Jakarta to care for his collection and perform the proper rituals. The 'touch of magic', not necessarily taken literally, accompanied the Wawrzyniak collection all the time and in fact, it still does, the word 'magical', very appealing to visitors to the museum, frequently appearing in the exhibition titles. ${ }^{8}$

The collector's interest grew rapidly, encompassing other areas of the extremely rich and diverse heritage of the Indonesian Archipelago, In I $_{2}$ his first f $_{6 M}$ period, aesthetic appeal and variety were his main concerns. The notions of access 

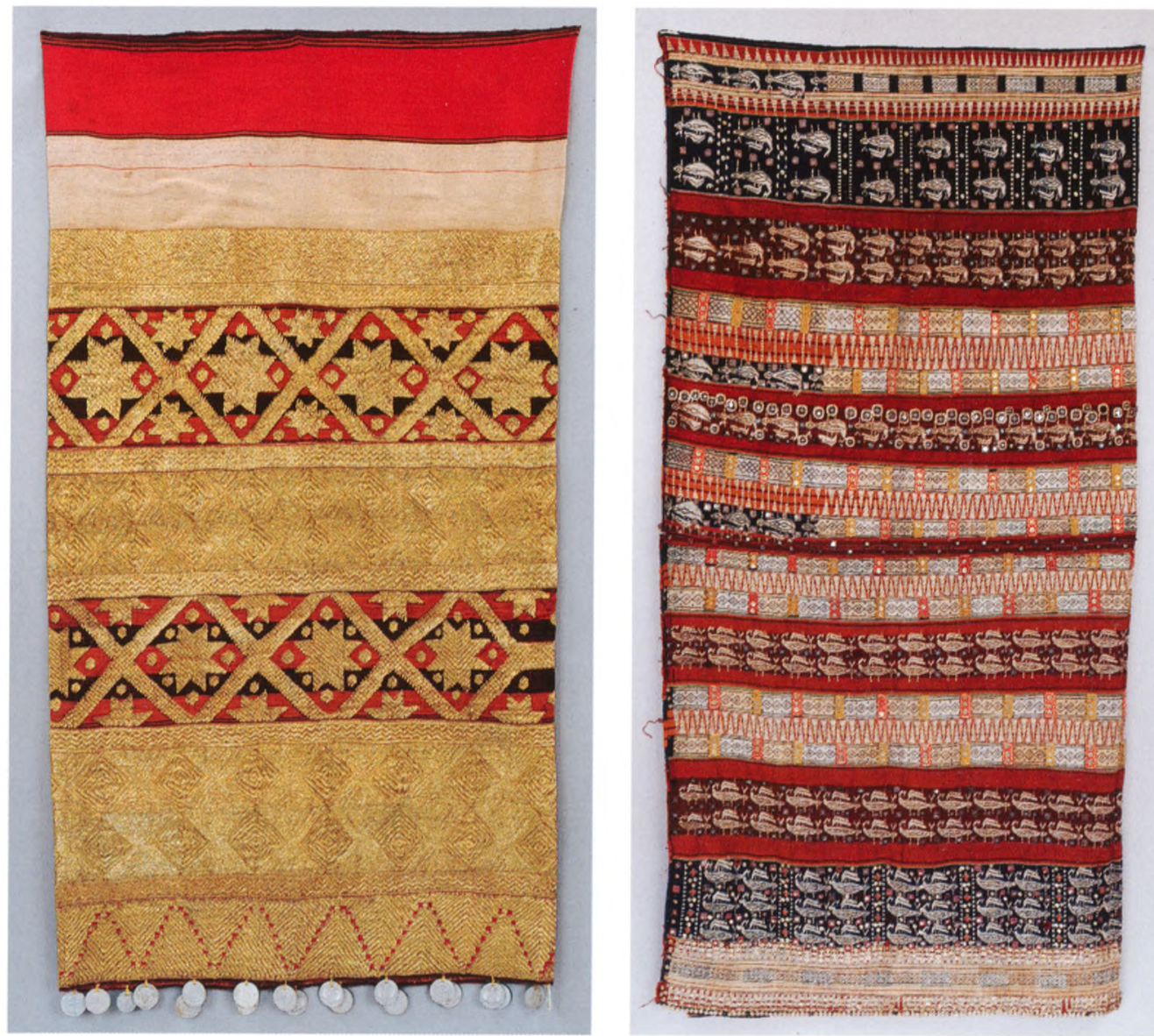

Fig. 2 (left) Tapis limar sekebar, cotton embroidered with metallic threads, coins, length $121 \mathrm{~cm}$, Indonesia, Sumatra, Lampung, late $19^{\text {th }}$ to $1^{\text {st }}$ half of $20^{\text {th }}$ C., APM, inv. no. 1457.

Fig. 3

Tapis balak (?), cotton, supplementary weft, appliqué, sequins, mirrors, metallic threads, embroidery, length $130 \mathrm{~cm}$, Indonesia, Sumatra, (North?) Lampung, late $19^{\text {th }}$ to early $20^{\text {th }} \mathrm{C}$., APM, inv. no. 5331. 'old', 'authentic' and 'traditional' played an important role in his approach, although contemporary art drew his attention as well, as we will see below. He travelled the country extensively, visiting all the most important islands, mainly as a 'treasure hunter'. ${ }^{9}$ During these years, thanks to extensive reading and important personal contacts with Indonesian collectors and connoisseurs (including, among others, Major Haryono Guritno, the aide-decamp and cultural advisor of President Sukarno), he gained knowledge and experience and earned a reputation in these circles as an expert, especially in the field of side arms.

Still, some of the objects were acquired from antique dealers, including from tukan luak, wandering peddlers, who provided Wawrzyniak with, among others, trade ceramics that were not yet typical collector's objects. As a result, in many cases the information about the territorial or ethnic origin is rather general and data about the sellers were unfortunately lost.

Textiles also quickly became a focal point of the Wawrzyniak collection, occupying a special place in the Asia and Pacific Museum. In total, the Indonesian textile collection consists of over 400 objects, half of which are Javanese batiks, mostly associated with Central Java, many of them rare and valuable examples of court batik tulis. About 100 ikats come from Bali, Flores, Timor, Sumatra, Sulawesi, Sumba Palue and Sawu golden thread 59:26AM

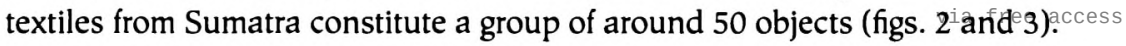




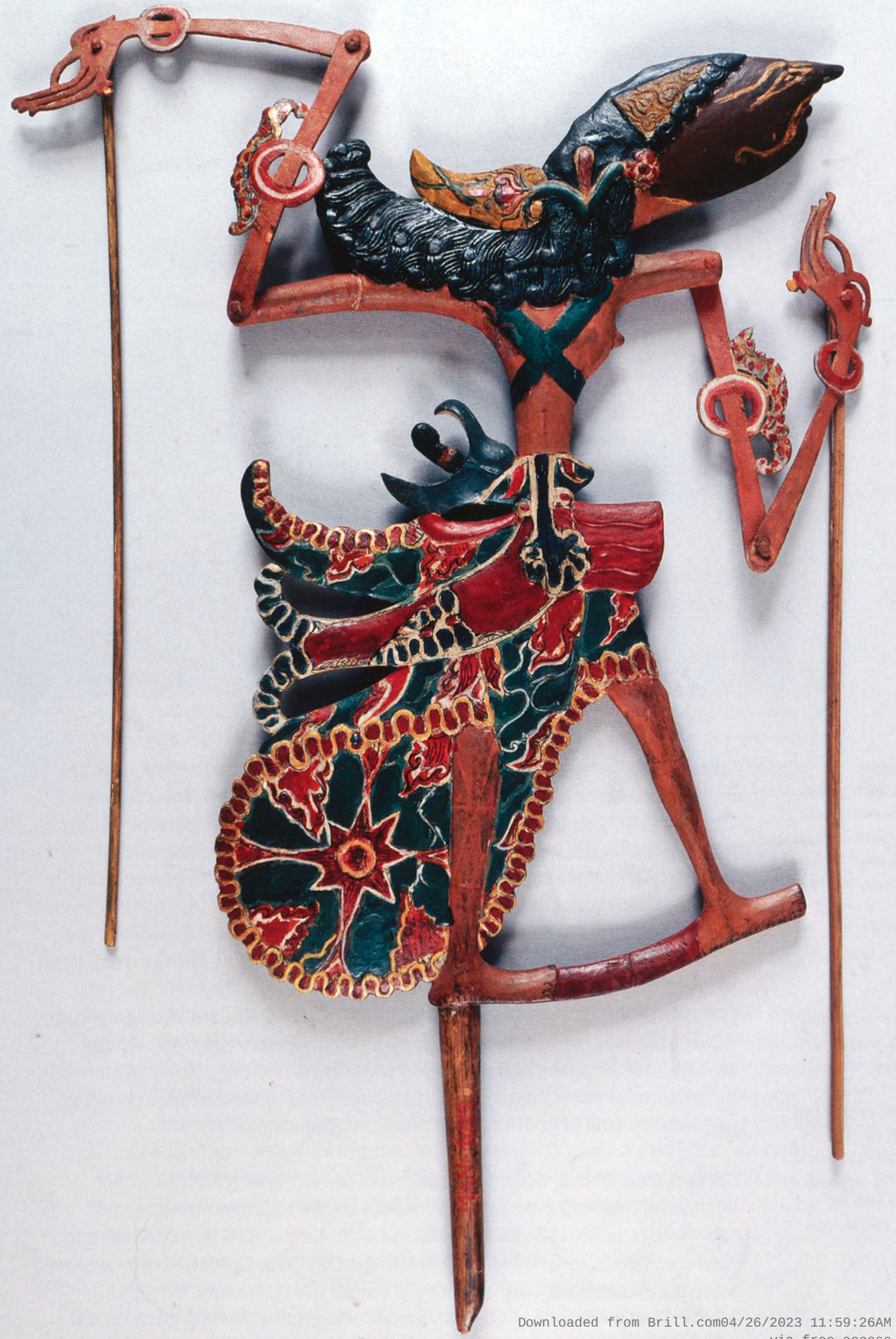




\section{< Fig. 4}

Wayang kerucil puppet of Aswatama Jatim, wood, leather, height 46,5 cm, Indonesia, East Java, ${ }^{\text {th }}$ half to mid-20 th $c$., APM, inv. no. 1099.
Already researched and exhibited in 1979, with an accompanying catalogue, ${ }^{10}$ regrettably they were never again displayed in their entirety. ${ }^{11}$ It seems worthwhile mentioning that, apart from the major collection strictly connected to the name of Andrzej Wawrzyniak, the selection of many other objects was also influenced by his personality. His Polish colleagues and friends, most of them also diplomats who resided in Indonesia around the same time, frequently made purchases encouraged and advised by him. Later, mostly in the 1970 s and 1980s, some of these objects found their way into the Museum's collection as donations or acquisitions. This situation applies to relatively many textiles, considered by their first owners at the moment of purchase as purely decorative items.

The next group of collectibles were those connected to theatre and music. This was and still is one of the strongest fascinations of Andrzej Wawrzyniak, who assembled a collection of wayang puppets. Javanese wayang kulit and wayang golek dominate, but there are also more rare wayang kerucil examples (fig. 4), including a set from the Bojonegoro region, a gift of Abdul Azis from Surabaya, one of Wawrzyniak's Indonesian friends. In total, the collection consists of nearly 1000 puppets, together with a wayang kulit screen, puppet trunks, lamps and other stage elements. To the area of performing arts also belong the wayang topeng masks, with an especially interesting set from Malang, East Java, dated to the late $19^{\text {th }}$ - and the early $20^{\text {th }}$ centuries, as well as the barong masks from Bali. Since the very beginning, musical instruments were also sought out by collectors and were part of the founding collection, especially different types of gongs, drums and idiophones. However, it was only in 2005 that two complete gamelan sets, dated to the 19th-and early 20th centuries, were acquired in Central Java.

On the other hand there are also paintings by outstanding modern Indonesian artists active in the period when Wawrzyniak stayed in this country, including Mochtar Apin, Agus Djaja, Hendra Gunawan, Batara Lubis (fig. 5), Ahmad Sadali and Srihadi Sudarsono. ${ }^{12}$ Then contemporary works of art, they now represent important insights into the different aspects of Indonesian modernity. It should be stressed that these were mostly personal gifts from the artists to Andrzej Wawrzyniak. A special case is Nyoman Gunarsa (born 1944), whose early career was supported and promoted by Wawrzyniak. The result of this cooperation is an extensive collection of early works by Gunarsa in the Museum's collection: oil paintings strongly influenced by his teacher, Affandi, but also much lighter and more individual watercolours and drawings.

Furthermore the collection encompasses a corpus of Balinese artefacts, with temple paintings, wooden sculptures and many works of art inspired by early 20th-century European influences: metal ware, such as betel sets, basketry and nearly all type of artefacts, especially those connected with Javanese, Balinese and Sumatran traditions. Numerous objects document the daily life, and especially the ceremonies and rituals, of Batak societies in Sumatra, as well as of other local ethnic groups from Kalimantan, Sulawesi and Nias. Among the evidence of Nusantara's involvement in the large net of intercultural exchange, there are over 240 pieces of trade ceramics dated from the $13^{\text {th }}$ - to the $19^{\text {th }}$ century that were found in the Indonesian Archipelago (fig. 7). ${ }^{13}$ Most of them belong to the types produced for the markets din China ${ }_{26 \mathrm{AM}}$ Vietnam and Thailand. It is important to remember that the collection was access 

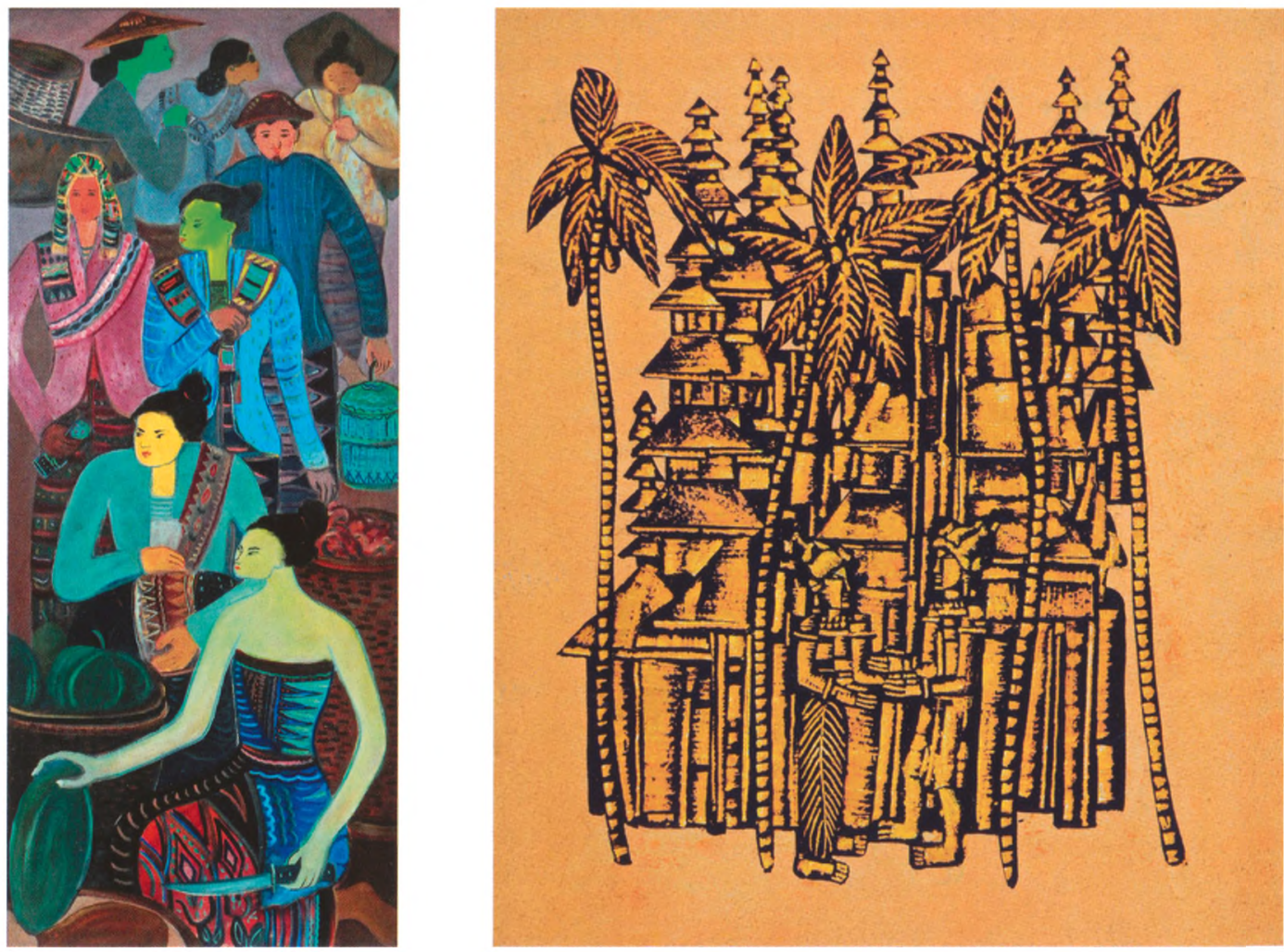

Fig. 5 (left)

Batara Lubis, Pasar

Senen, oil on canvas, $156 \times 67 \mathrm{~cm}$, Indonesia, 1960s, APM, inv. no. 2192.

Fig. 6

Roman Opalka, illustration to the book Skamienialy statek [Ship Turned into Stone] by Robert Stiller, gouache on paper, artist's technique, $28,5 \times$ 24,6 cm, Poland, 1967, APM, inv. no. 14952. created at a time when international interest in trade ceramics was in its infancy; the first Manila Trade Pottery Seminar, heralding the beginning of systematic research, was held in 1968 . However, this also means that these objects were approached more as interesting curios, and scant information exists concerning their origins.

During the subsequent years of the Museum's existence its director travelled to Indonesia almost annually, enriching the founding collection. Now the Indonesian objects make up over 5000 inventory numbers - over 20 per cent of the total resources.

In total the Museum's collection contains over 20,500 objects, covering most cultural circles on the Asian continent. The most important collections, apart from Indonesia, come from Mongolia, Nepal, India, Vietnam, Myanmar, Laos, China, Afghanistan, Uzbekistan, Turkmenistan, Tajikistan and many other countries. As for the Pacific section, the main focus lies on Melanesian collections, especially from regions in New Guinea and Vanuatu. Approximately 80 per cent of the present Asian collection was acquired thanks to the director's activities. These include objects he collected during his various diplomatic postings and while travelling throughout Asia; donations from his and the Museum's friends; purchases supported by local sponsors; and from Museum-inspired ethnological expeditions, prevalent in the 1980s, but now sadly discontinued. Andrzej Wawrzyniak's ability to forge close relationships and convince others of his ideas resulted in the only Polish museum where the number of donations is higher than the purchases; the antiquarian market has always been merely a marginal source for $1: 59: 26 \mathrm{Am}$ acquisition. This also implies that this Museum is still strongly influenced bys 


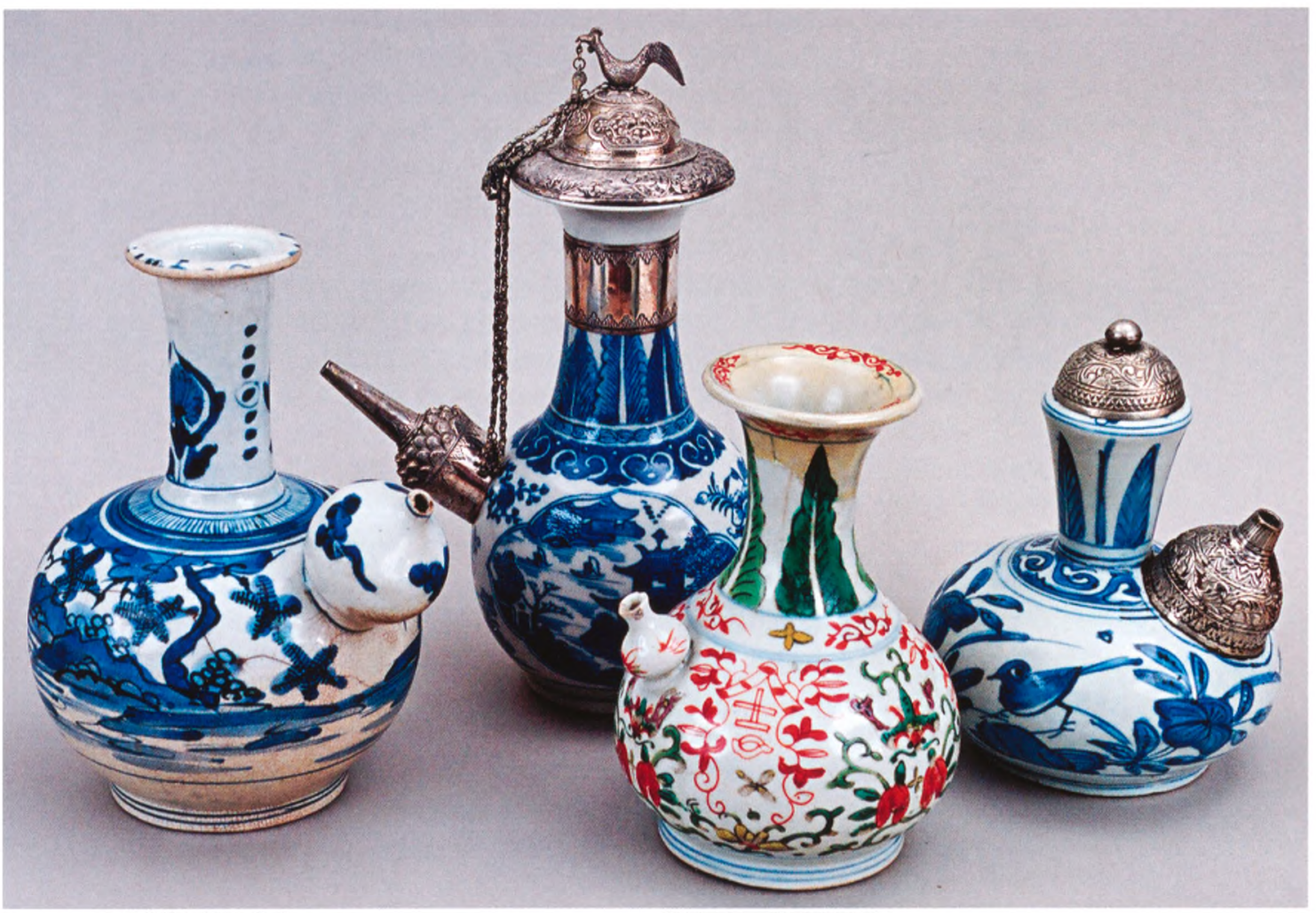

Fig. 7 Four porcelain kendi, left to right: height 21,5 cm, Japan, Arita, late $17^{\text {th }}$ C., APM, inv. no. 14600; height $28,3 \mathrm{~cm}$, China, with Indonesian silver mounting, late $18^{\text {th }}$ and $19^{\text {th }}$ C., APM, inv. no. 14725; height $18,6 \mathrm{~cm}$, China, $19^{\text {th }}$ c., APM, inv. no. 14735; height $18,8 \mathrm{~cm}$, South China, Fujian, with Indonesian metal mounting, late $16^{\text {th }}$-early $17^{\text {th }}$ c. (mounting probably much later), APM, inv. no. 14724 . the founder's personality and is developing much in a collector's way. ${ }^{14}$ Another special feature of the Museum's collecting activities is the interest in works by Polish artists inspired by Asian cultures and art traditions. Included among them is Andrzej Strumillo, an outstanding artist who travels extensively throughout the Asian continent, and whose works are the best represented in the Museum. As for the Indonesian area, the Museum's pride is a series of early works by the recently deceased, internationally renowned artist Roman Opalka (1931-2011), who in the 1960s illustrated Robert Stiller's books of Malaysian and Indonesian tales. Though he never visited Indonesia himself, he still drew inspiration from Borobudur reliefs and wayang puppet designs (fig. 6). ${ }^{15}$

\section{Striving for a permanent exhibition space}

The Indonesian collection shares the fate of the Museum in that it has never had a permanent exhibition space. This situation has been balanced by a policy of numerous temporary exhibitions. Art of the Southern Seas, the first exhibition of Andrzej Wawrzyniak's collection - still a private collection at the time - first opened in 1966 in Nowa Huta and then in Krakow, with the support of the Ethnography Museum in Krakow and its director Edward Waligóra as well as ethnographer Dr Janusz Kamocki. It aroused a vibrant, even if a little 'naïve', interest among the public and marked the onset of a long series of similar exhibitions all over the country. During the first years of the Museum's existence different parts of the Indonesian collection were exhibited extensively in several Polish gities and museums. This tradition : 59:26am was also upheld later, when the growing collection started encompassinge access 
other countries and cultural circles. Until now, nearly 100 Indonesian exhibitions (of a total of nearly 1000) were prepared, focusing mainly on particular categories of objects. Among the more important, one can mention Weapons of Indonesia (1974), Wayang - Javanese Theatre (1975), Indonesian Textiles (1979), Javanese Batiks (1985), Gamelan - Magical Sound of Indonesia (1986), Ramayana in the Indonesian Folk Theatre (1988), Indonesia - Bhinneka Tunggal Ika: Unity in the Diversity (1990), Nyoman Gunarsa (1995), Porcelain Road (2001), Magical Weapons from Heaven (2003), Indonesian Painting (also in 2003, presented on the occasion of the official visit to Poland by the President of the Republic of Indonesia, Megawati Soekarnoputri), and Conrad - Touch of the East (2004).

Now, finally, the likelihood of the first permanent exhibition in the Museum's history is becoming increasingly real. An attempt should be made to present an overview of all collections in an area measuring approximately 1100 square metres, with a special space reserved for Indonesia as the largest and oldest one. The preliminary concept already exists and the designers' work progresses, while the solutions for the Indonesian gallery are still being discussed.

This is a challenge for many reasons: selecting the most representative exhibits for a quite limited space, the manner of their presentation, and finally, the matter of the approach to the collection, which was for years somewhat 'taken for granted', whereas now it requires a fresh gaze and sometimes a new evaluation or updated research. The Museum intends to create an exhibition that will appeal not only to a broad audience representing as it does one of the most fascinating cultures of Asia - but also to specialists, for whom it can present an opportunity to research material that has been difficult to access for many years.

Dr Joanna Wasilewska has been working at the Asia and Pacific Museum in Warsaw since 1992. She is currently the senior curator and deputy director and supervises the Chinese and, partly, South-East Asian collections, with special focus on puppet theatre, trade ceramics and textiles. Another area of interest is the history of cultural contacts and exchanges between Europe and Asia. She is vice-president of the Polish Institute of World Art Studies (the former Polish Society of Oriental Art).

\section{Notes}

1. Photographs by Eugeniusz Helbert.

2. A somewhat analogical case is discussed by E. Waehle, 'A Congo Story from Oslo. Reflections on the Absence of an Exotic Art Market in Norway', Folk 43 (2001), pp. 137-50.

3. St. K. Potocki was the author of O sztuce $u$ dawnych czyli Winkelman polski [On the Art of the Ancient that is the Polish Winckelmann], first published in 1815. A Polish version of Johan Joachim Winckelmann's classic work, it also includes original introductory chapters by Potocki. They are devoted to the art of Asian countries, which is a very early example of including these areas in Western-conceived 'universal' art history. His observations were based partly on his own Chinese collection of which the remains are still stored in Wilanow Palace in Warsaw. 
on Chinese Art], Acta Universitatis Nicolai Copernici, Zabytkoznawstwo $i$ Konserwatorstwo XXXIII (2002), pp. 29-53.

4. The collection is now preserved at the Manggha Museum of Japanese Art and Technology in Cracow, specially founded for this purpose by the famous film director Andrzej Wajda.

5. Drawings documenting travels by such artists in the 1950s, including Aleksander Kobzdej, Tadeusz Kulisiewicz and Andrzej Strumillo, are also kept at the Asia and Pacific Museum.

6. He adopted the word 'Nusantara' as his second name, and used it especially among his Indonesian contacts, as Andrzej Nusantara Wawrzyniak.

7. David van Duuren, relying on photo-documentation only, suggested that this unusual object could be an 'a-typical amulet', shaped as a keris, dating from the preIslamic period. Personal communication, 2007.

8. K. Morawski, Magiczna broń z nieba. Krisy i inna broń indonezyjska ze zbiorów MAiP $w$ Warszawie [Magical Weapon from Heaven. Keris and other Indonesian Weapons from the APM in Warsaw Collection], Warsaw, 2003.

9. R. Schefold and H.F. Vermeulen (reds.), Treasure Hunting? Collectors and Collections of Indonesian Artefacts, Leiden, 2002. The term applied there seems to be very useful in this case.

10. N. Czukina and M. Wrońska, Tkaniny indonezyjskie w zbiorach Muzeum Azji i Pacyfiku [Indonesian Textiles in the Collection of the Asia and Pacific Museum], Warsaw, 1979 (with English summary).

11. References to the collection sourced from many other museums with more detailed documentation are of invaluable support here. The author of this text is much indebted to the Hood Museum of Art publication, which was invaluable in helping her update the knowledge about the APM tapis collection: M.L. Totton, Wearing Wealth and Styling Identity: Tapis from Lampung, South Sumatra, Indonesia, Hanover, New Hampshire, 2009.

12. Part of the collection was published in the exhibition catalogue: J. WasilewskaDobkowska, Indonesian Paintings from the [Asia and Pacific] Museum's Collection, Warsaw, 2003.

13. Most pieces were identified by referencing other world collections, including that of the Rijksmuseum in Amsterdam; for the reference to an object illustrated as fig. 6 (inv. no. 14724), see: C.J.A. Jörg and J. van Campen, Chinese Ceramics in the Collection of the Rijksmuseum, Amsterdam. The Ming and Qing Dynasties, Amsterdam, 1997, cat. 54. The collection was displayed in the exhibition Porcelain Road in 2001; J. Wasilewska-Dobkowska, Porcelanowy szlak. Ceramika Dalekiego Wschodu ze zbiorów Muzeum Azji i Pacyfiku w Warszawie [Porcelain Road. Far Eastern Ceramics in the Collection of the Asia and Pacific Museum in Warsaw], Warsaw, 2001.

14. A couple of Polish publications recount the history of the Museum and the collection; the most recent include A. Wawrzyniak: 'Muzeum Azji i Pacyfiku w Warszawie. Od kolekcji prywatnej do muzeum autorskiego' [The Asia and Pacific Museum in Warsaw. From a Private Collection to the 'Author's Museum'] in A. Gogut (ed.) 200 lat muzealnictwa warszawskiego. Dzieje i perspektywy [200 Years of Warsaw Museology. History and Perspectives], Warsaw, 2006, pp. 405-14. A compact review of the Indonesian collection was published as: J. WasilewskaDobkowska, 'Indonesian Art in the Asia and Pacific Museum, Warsaw, Poland', Arts of Asia 37/4 (2007), pp. 139-46.

15. The Ship Turned into Stone by Robert Stiller (publ. 1967) was one of my favourite children books in the 1970s. I was already working at the museum when the originals entered the collection in 1996. 


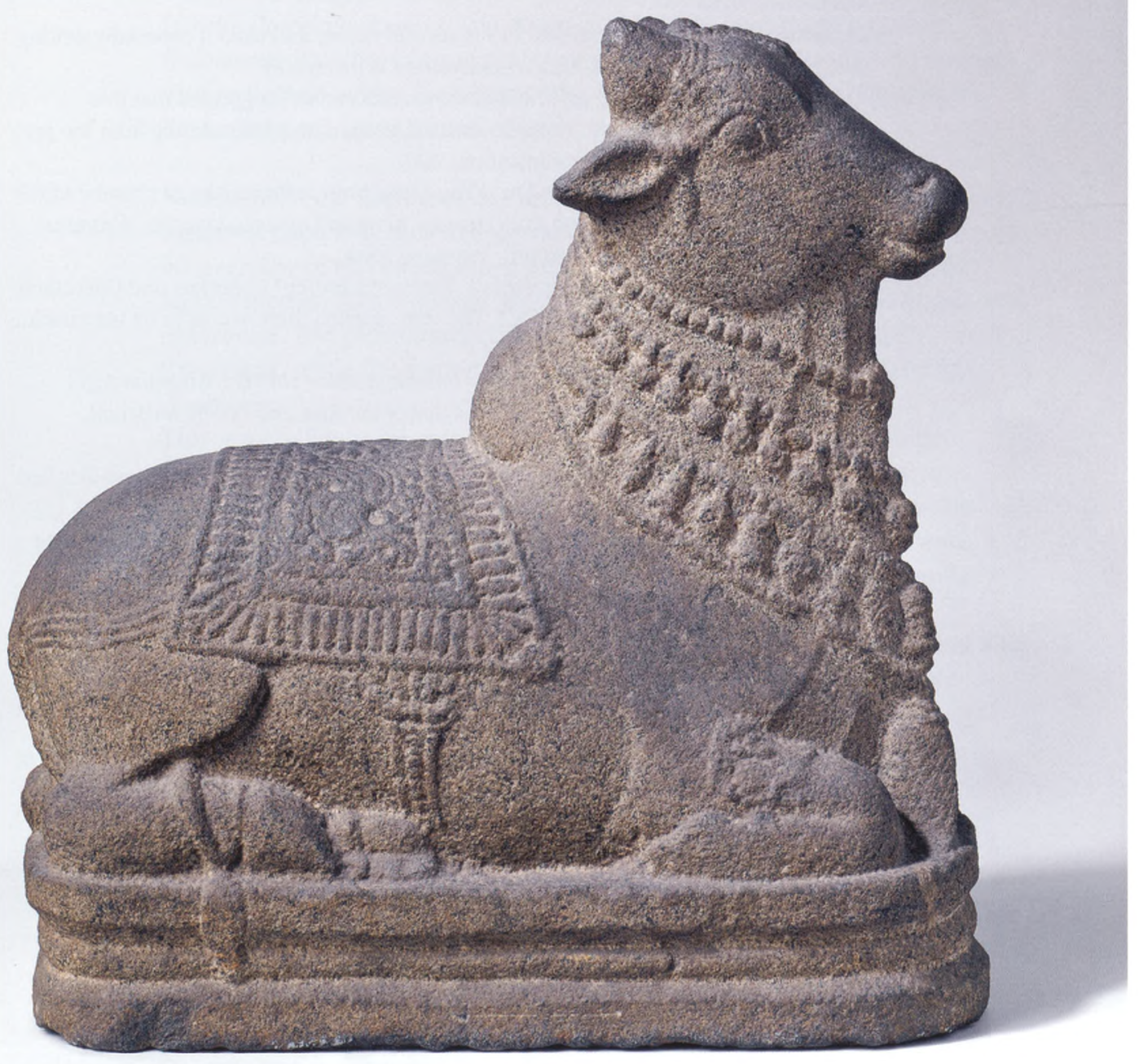

Afb. 1. De stier uit het Legaat Verburgt, grijze steen, I. 64 cm., h. 63 cm, ca. 11e-12e eeuw, Zuid-India.

Rijksmuseum Amsterdam, inv.nr. AK-MAK-

520. 